\title{
"Now Shall I See the Fall of Babylon": The Image of Spain in the Early Modern English Revenge Tragedy
}

\section{Introduction}

The Spanish Tragedy is one of the most important and influential tragedies in Elizabethan theatre. Taking up the classical Senecan model, Thomas Kyd's play is the first modern revenge tragedy, the first play with a truly Machiavellian villain, the first one with a play-within-the-play. Furthermore, it was, as Lukas Erne remarks, immensely successful-on stage as well as on the page-during the first decades after its publication: "Henslowe recorded no fewer than twenty-nine performances between 1592 and 1597, more than for any other play except The Jew of Malta and the lost The Wise Man of West Chester. Between 1592 and 1633, The Spanish Tragedy passed through at least eleven editions, more than any play by Shakespeare."1

The play inspired numerous imitations such as John Middleton's Revenger's Tragedy, George Chapman's Revenge of Bussy D'Ambois or Cyril Tourneur's Atheist's Tragedy, i.e. tragedies to which later literary history gave the genre heading of the revenge play. As a consequence of its rather spectacular success, aspects of Kyd's tragedy, such as the rhetorical genus grande of its dialogue, quite soon became subject to a number of parodies, for example in Ben Jonson's The Poetaster. Especially the figure of the mad revenger and the topic of melancholy madness left their mark on plays such as Shakespeare's Titus Andronicus or Hamlet, the latter transcending the genre by being a kind of meta-revenge play. Carol Thomas Neely sums up Kyd's enormous success and afterlife: “The influence of the play stretches far beyond this specific impact on the shape and substance of early modern tragedy into a host of imitations, allusions, and parodies that emerge even before the first quarto and continue through the closing of the theatres and beyond."

1 Lukas Erne, Beyond The Spanish Tragedy: A Study of the Works of Thomas Kyd (Manchester/ New York, NY: Manchester University Press, 2001), p. 95.

2 Carol Thomas Neely, Distracted Subjects: Madness and Gender in Shakespeare and Early Modern Culture (Ithaca, NY/London: Cornell University Press, 2004), p. 41.

Note: Parts of this paper will be published in Ingo Berensmeyer, ed.: Handbook of English Renaissance Literature (Berlin/New York, NY: De Gruyter, 2019). 
The impact is not restricted to the London theatres or Britain in general but stretches out across the channel. A number of adaptations of the play, three Dutch and three German versions-as well as the fact that it was part of the repertoire of troupes of English travelling players on the continent-secured its renown not only in Britain but also in the whole of Northern Europe. In a word, Kyd's Spanish Tragedy immediately became part of the early modern cultural memory and stayed vitally there up until the closing of the theatres in 1642.

All this is well known, and it is therefore all the more striking that one aspect of Kyd's tragedy, however central to its design, hardly had any impact on later plays: the image of Spain. Especially in later revenge tragedies, it is Italy rather than Spain which is chosen as a setting-with France and, of course, Denmark as notable exceptions. This begs the question why Spain, as the only other notable antagonist of England at the beginning of the age of imperialism and nation-building, does not figure any more prominently in later Elizabethan and Jacobean drama-especially considering The Spanish Tragedy's immense success and influence. The obvious answer, namely that the defeat of the Spanish Armada in 1588 brought about a change of focus as regards an obvious antagonist, simply does not seem to be a satisfying answer: although this date marks the end of immediate conflict, the rivalry between the two powers continued-especially in the New World colonies. Furthermore, as Eric J. Griffin has shown, anti-Spanish propaganda continued long after this date. In the following paper, I will take a look at the concept of Spain as a key-yet quite puzzling-element in the composition of the drama and ask why Spain is almost entirely overshadowed by Catholic Italy as a setting in later early modern drama.

\section{Spain}

In order to understand the politics of The Spanish Tragedy, the date of its composition is of vital importance. ${ }^{3}$ As most critics have pointed out, it is crucial to determine whether it was written before or after the Armada in 1588. The play was first published in 1592 in two rival editions, the first by Abel Jeffes, of which no copy has survived, and a second, "newly corrected" one by Edward White, of which one copy is extant. 1592 is therefore the latest possible date of composition, but since the play never mentions the Spanish Armada, it is likely that it was written before 1588. The earliest date of composition is easier to determine: the play must have been written after 1582, because it quotes from Thomas Watson's

3 For an overview of the history of composition see Erne, Beyond The Spanish Tragedy, pp. 55-60. 
Hekatompathia which was published that year. Thus most critics, such as Lukas Erne, David Bevington or Andrew Gurr, conclude that the play was written some time around the middle of the decade, i.e. between 1582 and 1587.

This date of composition exactly coincides with the growing tension between Elizabethan England and Hapsburg Spain as the two most important early modern rival powers and aspiring empires in the whole of Europe. The high point of English Renaissance culture therefore coexisted with this conflict, as Eric J. Griffin maintains: "The remarkable literary florescence we associate with the English Renaissance is exactly contemporary with England's protracted conflict with the Spanish Empire, an epoch that saw the emerging Protestant nation's tra-

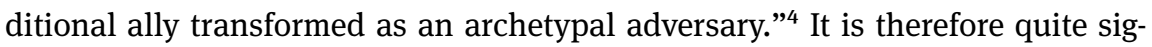
nificant that the play seems to be an immediate response to the contemporary political situation. It thematises the growing tensions, yet without any mention of the Anglo-Spanish conflict, focusing solely on the political situation on the Iberian Peninsula instead.

The annexation of Portugal in 1580 by Philip II and the resulting unification of the Iberian Peninsula constitutes the political background of the plot. Yet, it is not the war between Spain and Portugal, which led to the latter's annexation, that the play begins with, but rather a minor conflict in the aftermath of this war. This is quite clear, since Portugal is ruled not by an independent sovereign but by a viceroy. The battle mentioned in the first scenes may instead refer to a later minor conflict fought at Terceira, a fact that Griffin reads as an allusion to the topos of Spanish hubris and ambition gaining prominence in England in the 1580s. ${ }^{5}$ However that may be, the opening scenes with the imprisonment of Balthazar, son to the Viceroy of Portugal, clearly allude to the unification of the Iberian Peninsula. This would have been powerful stuff for a tragedy:

Philip II's assumption of the Portuguese throne in 1580 sent shockwaves through a Europe embroiled in a military and ideological struggle that would not exhaust itself until well into the next century. Suddenly, the balance of power had swung, perhaps decisively, in the direction of the Spanish Hapsburgs and their allies. The English and the French especially feared what a united Iberia might be able to accomplish [...]. ${ }^{6}$

Furthermore, the years between 1570 and 1588 were not only a time of growing tension between the aspiring nations, but also one in which anti-Spanish

4 Eric J. Griffin, English Renaissance Drama and the Specter of Spain: Ethnopoetics and Empire (Philadelphia, PA: University of Pennsylvania Press, 2009), p. 1.

5 See Griffin, "Nationalism, the Black Legend, and the Revised Spanish Tragedy," English Literary Renaissance 39.2 (2009), pp. 336-370, p. 344.

6 Griffin, Specter of Spain, p. 68. 
prejudice became manifest. The growing Hispanophobia in these years became manifest in a number of anti-Spanish clichés that were later subsumed under the name of the Black Legend. Subsequently, the English came to think of the Spanish in terms of a fundamental otherness, an alterity that was to shape all forms of racial and ethnic prejudice in later centuries. ${ }^{7}$ Against this background it seems only probable that Kyd's play was influenced by this kind of thinking in one way or another, as J. R. Mulryne states:

[...] Hispanophobia was a strand in the English consciousness in the 1570s, and one that broadened and intensified as the 1580 s led towards the Armada of 1588. In the immediately following years, enmity between the nations increased rather than slackened. [...] It is hard to think that Kyd's audience in the 1580s, at the Rose or elsewhere, was unaffected by such widely disseminated attitudes when attending a play set in the Iberian peninsula and called The Spanish Tragedy. ${ }^{8}$

Given these historical circumstances, one would expect the play to be openly anti-Spanish or at least that it would provide an image of a world that was characterised by an increasing tension immediately preceding the year 1588 .

Several scholars have attempted to read the Spanish Tragedy in the context of the Black Legend. Already in 1971, Ronald Broude argued against both a too literal and a too figurative reading of the play's setting:

However, relations between England and Spain in the 1580's were such that no English audience could have ignored the setting of a play on Spanish soil, and knowing this, no playwright of Kyd's acumen would have chosen such a setting without intending in some way to exploit it. While the Spain of Kyd's play cannot be taken literally as the historical Spain, it may certainly be understood as symbolic of a nation in which wickedness and depravity reign. ${ }^{9}$

Steven Justice's interpretation focuses on the anti-Catholic tendency of the plays-which leaves Denmark as the odd country out:

The English revenge tragedies are not set in England, but in Catholic Spain, Catholic Italy, and a Denmark stalked by soi-disant purgatorial spirits. Their audiences learned from pulpit, pamphlet, and ballad that Spain was bad because of the Roman Church, and that the Roman Church was bad because it had rejected Christ's new dispensation. Kyd creates

7 See William Saunders Maltby, The Black Legend in England: The Development of Anti-Spanish Sentiment, 1558-1660 (Durham, NC: Duke University Press, 1971).

8 J. R. Mulryne, "Nationality and Language in Thomas Kyd's The Spanish Tragedy," in: JeanPierre Maquerlot and Michèle Willems, edd., Travel and Drama in Shakespeare's Time (Cambridge: Cambridge University Press, 1996), pp. 87-105, p. 88.

9 Ronald Broude, “Time, Truth, and Right in The Spanish Tragedy,” Studies in Philology 68 (1971), pp. 130-145, p. 144. 
from these slogans of popular propaganda the dramatic images and patterns of action that make his entertainment a powerful one..$^{10}$

And Andrew Hadfield maintains: “Thomas Kyd's Spanish Tragedy [...] represented its Spanish protagonists trapped within a destructive cycle of revenge that was controlled by pagan gods, showing that the Spanish were pagan rather than Christian, and so were damned."11

Yet, looking at the play, at least in its originally printed form from 1592, these readings of The Spanish Tragedy as shaped by anti-Spanish prejudice seem puzzling, as Kyd's play never makes open use of any elaborate propaganda. Although some critics describe the setting of Catholic Spain as corrupt and debased, such a view is more informed by later revenge tragedies than by Kyd's play itself. The claustrophobia evoked by a corrupt society in, for instance, John Webster's Duchess of Malfi is at least as important as the plot itself. The Spanish Tragedy, by contrast, does not show a perverted society void of morals and with hardly any positive character in the whole play. Rather, as Lukas Erne remarks, "the play precisely lacks the anti-Spanish tone that might be expected from a work composed around the time of the Armada. The Spanish king is depicted as a generous character who is conciliatory throughout towards the Portuguese."12

When in Act One Balthazar is brought as a prisoner before the King, he is welcomed in the most noble manner:

BALTHAZAR: The trespass that my father made in peace

Is now controlled by fortune of the wars,

And, cards once dealt, it boots not ask why so.

His men are slain, a weakening to his realm,

His colours seized, a blot unto his name,

His son distressed, a corsive to his heart;

These punishments may clear his late offence.

KING: Ay, Balthazar, if he observe this truce

Our peace will grow the stronger for these wars.

Meanwhile live thou, though not in liberty,

Yet free from bearing any servile yoke,

For in our hearing thy deserts were great,

And in our sight thyself art gracious. ${ }^{13}$

10 Steven Justice, "Spain, Tragedy, and The Spanish Tragedy," Studies in English Literature, 1500-1900 25.2 (1985), pp. 271-288, p. 287.

11 Andrew Hadfield, "Introduction: Shakespeare and Renaissance Europe," in: Hadfield and Paul Hammond, edd., Shakespeare and Renaissance Europe (London: Thomson Learning, 2005), pp. 1-20, p. 5.

12 Erne, Beyond The Spanish Tragedy, p. 90.

13 Thomas Kyd, The Spanish Tragedy [1592], ed. David Bevington (Manchester/New York, NY: Manchester University Press, 1996), 1.2.138-150. All references to Kyd's play are to this edition. 
Two scenes later, the end of the war is conceived of as a newly found peace built on mutual esteem: "KING: [...] Spain is Portugal, / and Portugal is Spain; we both are friends, / Tribute is paid, and we enjoy our right." ${ }^{14}$ Although the annexation of Portugal by Spain features as the setting, the political background and of course also the trigger for the tragic plot, it creates no obvious atmosphere of claustrophobia or threat. The 1592 version of The Spanish Tragedy published by White is, in a word, no play of anti-Spanish propaganda.

Historicising The Spanish Tragedy, Eric J. Griffin differentiates between this first publication of the play and later versions as "[t]he texts that comprise Kyd's drama[.]"15 He also has to concede that "[t]he earliest printed version of The Spanish Tragedy largely fails to register the Black Legend of Spanish Cruelty"; ${ }^{16}$ he states, however, that "into the later versions of The Spanish Tragedy the dark, essentializing 'humors' of the Black Legend will steadily creep." ${ }^{17}$ The example he gives is the famous frontispiece of the 1615 edition of the play (see Figure 1) where Lorenzo, Horatio's murderer, is depicted with a black face, therefore mirroring the contemporary prejudice against "blackamoors," hinting at the possibility that "the 'Spanish villain' had become conventionally represented as 'tawny' or dark-skinned[.]”'18

Nevertheless, it is rather striking that, despite the Black Legend, the immediate political and topographical setting of The Spanish Tragedy is one of the few aspects that did not influence later Elizabethan and Jacobean revenge tragedies. This is also the conclusion drawn by Lukas Erne: "If the 'Spanishness' of The Spanish Tragedy had originally contributed so much to the play's popularity as some critics assert, it would seem surprising that none-to my knowledge-of the innumerable early allusions to Kyd's play takes up its historical relevance or points to its alleged anti-Spanish prejudice." 19

This creates a paradoxical situation. On the one hand, The Spanish Tragedy is one of the most influential early modern plays, on the other hand, the antiCatholic claustrophobia that characterises later revenge tragedies does not seem to be an immediate effect of Kyd's play.

While the influence on later drama and theatre is clearly palpable, the play's sources present an unusual problem. One clear influence is Seneca, whose

14 1.4.132-134.

15 Griffin, "Nationalism,” p. 337.

16 Ibid.

17 Griffin, “Ethos, Empire, and the Valiant Acts of Thomas Kyd's Tragedy of 'the Spains', English Literary Renaissance 31.2 (2001), pp. 192-229, p. 229.

18 Griffin, "Nationalism," p. 339.

19 Erne, Beyond The Spanish Tragedy, p. 91. 


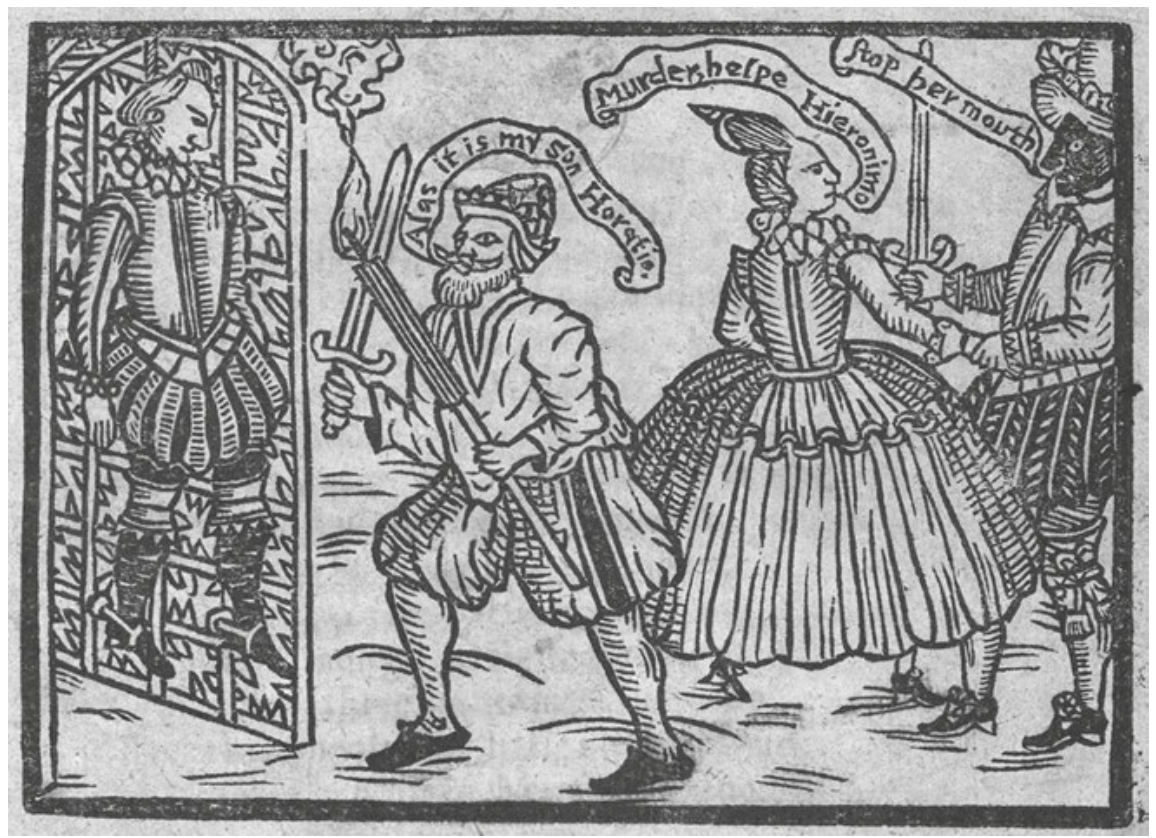

Figure 1: Thomas Kyd, The Spanish Tragedy, London 1615 (detail).

Roman tragedies establish the blueprint for the play's revenge plot. The playwithin-the-play in Act IV refers to Henry Wotton's tale "Soliman and Perseda"; the opening monologue describing Andrea's descent into the underworld is taken from Virgil's Aeneid; and the historical setting is clearly an allusion to the wars between Portugal and Spain between 1578 and 1582 and the ensuing unification of the Iberian peninsula. It is extraordinary, however, that no singular source for the main plot has been identified. The Spanish Tragedy has been described as one of the few Renaissance plays without an "obvious single source," ${ }^{20}$ as Andrew Gurr remarks. Yet it is highly controversial whether this is really the case. Since it was unusual in Elizabethan theatre to compose a play without a prose narrative such as a novella as a source, Lukas Erne concludes that it is more likely that Kyd used a source which has not been identified or which is lost. ${ }^{21}$ Whether this lost source text is responsible for the fact that Kyd's tragedy is not characterised by anti-Spanish propaganda therefore remains a riddle.

20 Andrew Gurr, “Introduction," in: Thomas Kyd, The Spanish Tragedy, edd. Gurr and J. R. Mulryne (London: Methuen, 2009), pp. vii-xxviii, p. viii.

21 See Erne, Beyond The Spanish Tragedy, p. 50. 
All this leads to the conviction that the Spain of The Spanish Tragedy has become detached from the socio-political tension that grew in the 1580 s and which came to be known as the Black Legend. In other words, the Spain of The Spanish Tragedy-although without a doubt an empire-can be viewed in broader terms; it has the quality of a general concept, an aspiring nation that can be easily exchanged for another. The first European translation seems to underline this hypothesis: Jakob Ayrer's Tragedia von dem griegischen Keyser zu Constantinopel vnnd seiner tochter Pelimperia mit dem gehengten Horatio. The unproblematic transition from the Iberian peninsula to Constantinople within just one translation suggests that Spain as such is of no central concern to the dramatic architecture of The Spanish Tragedy. What is more important than the actual historico-political setting is therefore the discussion of the concept as such, the construction of an early modern nation and an early modern empire, a notion that even finds expression in the name of one of the key characters: Bel-Imperia.

\section{Empire- and Nation-Building}

At the end of the sixteenth and also during the seventeenth centuries, Kyd's play was not primarily known as The Spanish Tragedy but rather by the name of its protagonists. In England during the 1590s it was known as Hieronimo, the German repertoire list of 1626 mentions a Tragoedia von Hieronymo Marschall in Spanien and a German manuscript as well as a Dutch translation are called Jeronimo. This focus on the revenger suggests that contemporary audiences were attracted by the one aspect of Kyd's play that is still the most striking today: revenge. Hence, the play's emphasis on action and performance seems to veil the national background of the setting.

The female protagonist is of key importance in order to understand the imperial background. As mentioned above, the title of Ayrer's play mentions not only the Persian emperor but also his daughter Pelimperia; and another German version of the tragedy, Kaspar Stieler's tragic drama ("Trauerspiel”) of 1680 is called Bellemperie. Bel-Imperia is indeed a key figure in the construction of the play, especially as regards the concept of empire. In the original drama, BelImperia is the Duke of Castile's daughter and the sister of the principal Machiavellian villain, Lorenzo. She is central to the plot of the tragedy, since, allegorically, she stands for the empire, or rather, for imperial aspirations and temptations. She is "the beautiful, war-inspiring, idol of empire."22 As such, she is a very complex

22 Griffin, Specter of Spain, p. 75. 
figure: the first syllable of her name could either refer to the Latin bella, designating beauty and hence attraction, or to bellum, referring to warfare. Eric Griffin has identified yet another, not Latin but Hebrew, meaning of the prefix which immediately creates a link between the heathen Latin meaning and a biblical and hence religious denotation:

For even as "Bel" resounds with "beauty" and "war," it also strikes a far more apocalyptic note, ringing in a more culturally relevant biblical seductress [...]. As we are instructed "Against idolators" in the Geneva Bible (or in any number of like-minded Elizabethan sermons and commentaries), "Bel" is one of the "chiefe idoles of Babylon."23

Griffith's reading of "Bel” as a reference to the Babylonian context is based on other passages of the play which clearly establish a connection with Babylon. In Act Four, Hieronimo, immediately before he stages the bloody play-within-theplay which sets an end to the tragedy, announces: "Now shall I see the fall of Babylon, / Wrought by the heavens in this confusion. / And if the world like not this tragedy, / Hard is the hap of old Hieronimo."24

Bel-Imperia is therefore a multifaceted and ambiguous character. On the one hand, she is a tempting seductress, on the other, her charm creates chaos and warfare. This is mainly due to the fact that she is not as pure and innocent as one might first be inclined to think. Not only does she love and is loved by Horatio and is the cause of Balthazar's desire, which is at the same time the imperial desire to unite Spain and Portugal. But right at the start of the tragedy, a sexual relationship with Andrea is also hinted at: "ANDREA: In secret I possessed a worthy dame, / Which hight sweet Bel-imperia by name."25

In a word, as an allegorical figure, Bel-Imperia is dangerous and probably even immoral, although, when it comes to the action on stage, she is clearly on the side of the protagonists. That this desire for empire closely links sexual love with warfare becomes obvious in the scene immediately preceding the murder of Horatio:

HoRATIO: If Cupid sing, then Venus is not far.

Ay, thou art Venus, or some fairer star.

BEL-IMPERIA: If I be Venus thou must needs be Mars, And where Mars reigneth there must needs be wars.

HoR.: Then thus begin our wars: put forth thy hand, That it may combat with my ruder hand.

BEL-IMP.: Set forth thy foot to try the push of mine. ${ }^{26}$

23 P. 73 and n. 27 on p. 231. The biblical reference is to Isa 45 and 46.

24 Kyd, The Spanish Tragedy, 4.1.195-198.

25 1.1.10 f.

26 2.4.32-38. 
The amorous warfare between the two lovers leads to a metaphorical play with the sexual connotations of the term death: "BEL-IMP.: O, let me go, for in my troubled eyes / Now may'st thou read that life in passion dies. / HoR.: O, stay awhile and I will die with thee; / So shalt thou yield and yet have conquered me."27 This metaphorical notion of death then immediately leads to Horatio's literal death on stage. Hence, the attraction of empire is both beautiful and lethal.

All this does not resolve the initial question why the play does not make use of the anti-Spanish sentiment growing during the 1580s. Kyd could have easily produced a play full of anti-Spanish propaganda; yet this is not the case.

I believe that the reason for this lies in a feature inherent to the genre of revenge tragedy. Although Kyd uses the Iberian Peninsula as his setting and the unification of Spain and Portugal as historical background, the play replaces this historico-political setting with a literary rather than a literal setting. His Spain is equivalent to Italy in later Elizabethan and Jacobean tragedies: it is the creation of an Other against which the tensions and conflicts of the aspiring nation and empire that England is about to become can be described more clearly. In this sense, Kyd's Spain is made, it is performatively created, just as Italy is "made in and for England,"28 as Manfred Pfister states. What is important is that this notion of "Other" is not primarily a political antagonist but rather represents an overcome past; it is integrated into the national self-construction rather than built up as a potential enemy. Against this backdrop it becomes clear that "national or cultural identity as a sense of identity enacted in individual and collective performances"29 elucidates the fact that The Spanish Tragedy is more concerned with the political tensions in England itself than with the tensions between Spain and England. Or, to put it more directly: the play refashions these tensions as an inner conflict in early modern England, a conflict that is at the heart of the genre of the revenge tragedy.

\section{Revenge}

As would be expected, the question of revenge has been discussed over and over again in investigations into the nature of the revenge tragedy genre. Revenge was

$272.4 .46-50$.

28 Manfred Pfister, "Introduction: Performing National Identity,” in: Pfister and Ralf Hertel, edd., Performing National Identity: Anglo-Italian Cultural Transactions (Amsterdam/New York, NY: Rodopi, 2008), pp. 9-28, p. 10.

29 Ibid. 
illegal under Elizabethan and Jacobean law and furthermore, as Eleanor Prosser has shown, condemned by the public. ${ }^{30}$ A famous contemporary point of reference is Francis Bacon's condemnation of revenge as "a kinde of Wilde Justice." 31 In this brief essay, Bacon sums up the entire dilemma of revenge: "For as for the first Wrong, it doth but offend the Law; but the Revenge of that wrong, putteth the Law out of Office." ${ }^{32}$ The problem that the Revenger in the Elizabethan revenge tragedies faces is the fact that the law is in no position to set things right, be that because the King, as in Hamlet, is himself the murderer or, as in The Spanish Tragedy, because the revenger-Hieronimo as Knight Marshall-himself represents the law and yet is powerless.

Despite its social condemnation, revenge was an immensely popular topic on the stage. For one thing, the extremely bloody plays were successful because they were fraught with action. But there is also a more general explanation: the plays in the wake of Kyd's tragedy brilliantly capture the claustrophobia of the age. The conflict within the early modern revenge tragedy transcends individual mishaps or conflicts between nations and encapsulates the general tension of a period in transition from a late medieval to a modern society.

Thomas Rist has interpreted the entire genre of the revenge tragedy as an early modern attempt to come to terms with the religious change from traditional Catholic to Protestant doctrine:

To a culture owing oratory, literature, painting, architecture, even churches and theatres to the "social habit" of the art of memory, especially to one in which death was remembrance's “animating impulse”, England's Reformed challenge to Christian "memoria” was an earthquake. [...] Revenge tragedy regularly enacts remembrances of the dead, drawing attention to the period's change in religious practices and deriving significance from them thereby. ${ }^{33}$

The theory that the theatre may be a compensation for the loss of the performative Catholic mourning rites-a thought that is heavily indebted to Stephen Greenblatt's Hamlet in Purgatory - has its merits, but it makes more sense to regard the plays in an even broader perspective. They negotiate the many possible ways to interpret the world at a time when conflicting models are simultaneously at hand. Therefore, they offer a view of the insecurity of an age stuck between the medieval

30 See Eleanor Prosser, Hamlet and Revenge (Stanford, CA: Stanford University Press, 1967).

31 Francis Bacon, The Essayes or Counsels, Civill and Morall [1597/1612/1625], ed. Michael Kiernan (Oxford: Clarendon Press, 1985), p. 16.

32 Ibid.

33 Thomas Rist, Revenge Tragedy and the Drama of Commemoration in Reforming England (Aldershot/Burlington, VT: Ashgate, 2008), pp. 4-6. 
and the modern worldview. With a reference to Shakespeare's late tragedies but also on a more general note, Sabine Schülting states:

This disillusionment surely needs to be seen in connection with the fundamental cultural transition which became apparent at the end of sixteenth century: the political instability, the disintegration of social hierarchies, the social tensions, and the economic crisis need to be considered as much as the Protestant challenge to Renaissance optimism, the questioning of medieval opinions, and the resulting feeling of a decentring of the world and the individual. [...] Language seems incapable of depicting this reality unambiguously, and the world is felt to be a theatre on whose stage humans play an - often absurd and meaningless - role. ${ }^{34}$

The general insecurity-with regard to religion, society, government, the individual and language-that characterises Shakespeare's later tragedies and Jacobean tragedy in general finds its precursor in Kyd's play of the 1580s. It is exactly this coexistence of disparate worldviews-which in a German idiom is called Gleichzeitigkeit des Ungleichzeitigen - that leads to the tragic events in Kyd's play. Accordingly, Tanya Pollard describes the social changes that had an immediate effect on, and are reflected in, the genre of the revenge tragedy:

While this basic plot motif may have an enduring appeal for audiences, social and political changes in Elizabethan England created a heightened demand for it. Revenge redresses injustice caused by abuses of power, and the distribution of power in this period was not only hierarchical, but increasingly unstable. The Elizabethan court's growing monopoly on power weakened the status and fortunes of the aristocratic classes, as well as those who depended on them for employment and patronage, unsettling the traditional social order and creating anxiety and bitterness among those who could no longer count on the continuation of their way of life..$^{35}$

The impact of the paradigm change from a medieval to a modern worldview has been most famously described by Michel Foucault in The Order of Things.

34 "Diese Desillusion steht sicherlich im Zusammenhang mit dem grundsätzlichen kulturellen Wandel, der zu Ende des 16. Jh.s offenbar wurde: Die politische Instabilität, der Aufbruch gesellschaftlicher Hierarchien, die sozialen Spannungen und die ökonomische Krise wären ebenso zu nennen wie die protestantische Dämpfung des Renaissance-Optimismus, die Infragestellung mittelalterlichen Gedankenguts und das damit verbundene Gefühl der Dezentrierung der Welt und des Individuums. [...] [A]bsolute Wahrheiten sind unsicher geworden. [...] Die Sprache scheint ungeeignet, die Wirklichkeit eindeutig zu bezeichnen, und die Welt wird als Theater empfunden, auf dessen Bühne der Mensch eine-oftmals absurde und sinnlose-Rolle zu spielen hat.” (Sabine Schülting, “Die späteren Tragödien,” in: Ina Schabert, ed., ShakespeareHandbuch: Die Zeit. Der Mensch. Das Werk. Die Nachwelt (Stuttgart: Kröner, 2000), pp. 529-574, p. 531. My translation)

35 Tanya Pollard, “Tragedy and Revenge,” in: Emma Smith and Garrett A. Sullivan Jr, edd., The Cambridge Companion to English Renaissance Tragedy (Cambridge: Cambridge University Press, 2000), pp. 58-72, pp. 59 f. 
According to Foucault's generalising analysis, this change affects first and foremost the linguistic sign: during the Renaissance, the sign ceases to bear a fundamental resemblance to its referent and instead comes to represent it arbitrarily:

This being so, the written word ceases to be included among the signs and forms of truth; language is no longer one of the figurations of the world, or a signature stamped upon things since the beginning of time. The manifestation and sign of truth are to be found in evident and distinct perception. It is the task of words to translate that truth if they can; but they no longer have the right to be considered a mark of it. Language has withdrawn from the midst of beings themselves and has entered a period of transparency and neutrality. ${ }^{36}$

In his brief yet highly illuminating analysis of Hamlet, Dieter Fuchs describes the genre of the revenge tragedy as negotiating the shift from a medieval aristocratic to the classical bourgeois episteme, which he depicts as a clash between two conflicting sign systems:

The dispositif of revenge negotiated within revenge tragedy thematises a paradigm shift within the social sign system, which takes its beginning at the turn of the sixteenth to the seventeenth century, to be fully differentiated in the Sattelzeit of the eighteenth. Against the background of the residual semiotics of feudalism, the emerging court aristocracy and early bourgeoisie struggle for primacy and social authority by generating new orders of signs. ${ }^{37}$

This notion can also be applied to The Spanish Tragedy. The revenger Hieronimo is the representative of an overcome traditional society with a feudal concept of legitimacy and law as well as a Catholic system of morals and ethics. His antagonist is the Machiavellian villain, Lorenzo, who is able to manipulate this system according to his own interests.

According to Foucault, the medieval sign system is built on the resemblance between sign and referent: the message semiotically merges with its content and does not arbitrarily signify it. Bel-Imperia's letter written in blood is one example of this merging; the play-within-the-play is another. This play is not concerned

36 Michel Foucault, The Order of Things: An Archeology of the Human Sciences [Les mots et les choses, 1966], trans. Alan Sheridan (London/New York, NY: Routledge, 2010), p. 62.

37 "Das in der revenge tragedy verhandelte Dispositiv der Rache thematisiert einen lebensweltlich stattfindenden Umbruch des sozialen Zeichenfundus, der an der Schwelle vom 16. zum 17. Jahrhundert einzusetzen beginnt und in der Sattelzeit des 18. Jahrhunderts seine volle Ausdifferenzierung erreicht. Vor dem Hintergrund der traditionellen Semiotik des Feudalismus ringen die neu entstehenden Schichten der Hofaristokratie und des Frühbürgertums um die Schlüsselautorität im Gemeinwesen, indem sie neue Zeichenordnungen generieren.” (Dieter Fuchs, "Hamlet und die 'Poetik des Übergangs': Showing und Telling in der frühzeitlichen Rachetragödie," Wissenschaftliches Seminar Online 3 (2005), pp. 24-29, p. 24, http://www.shakespeare-gesellschaft.de/seminar/ausgabe2005 (retrieved: 31 July 2014). My translation) 
with mimetically depicting reality: it does not show the killing, it is the killing itself. The sign, therefore, in a last tragic act merges with the referent.

The outcome of this tension between an overcome past and an uncertain future is yet unclear, i.e. the question whether it leads to absolutism or early republican forms of democracy remains unresolved; but the Renaissance tragedy as a genre bears witness to the fundamental destabilisation of society. In this sense, Spain does not primarily represent the Catholic and imperial Other, it rather represents England's own Catholic and feudal past that is incorporated into a society that is depicted as unstable and in a severe crisis. Spain is therefore not the historico-political Other, but an incorporated Other in the process of England's early modern formation as a nation and aspiring empire. Griffin describes this as a literary translatio imperii:

[W] must reemphasize that it is not Hieronimo's action itself that is to blame for the carnage. Rather, it is the prevailing ethos of the society in which his valiant act is carried out-the theological system that shapes, supports, and sustains the Roman Catholic social order from which Protestant England has so recently withdrawn-that determines its meaning. ${ }^{38}$

This can be illustrated by the very last scene of The Spanish Tragedy. At the end of the play, Hieronimo bites out his tongue after having betrayed, in a final extended monologue, all the information relevant for an understanding of his deeds. After this extended explanation, the king, bafflingly, exclaims:
KING:
Why speak'st thou not?
HiERONIMO: What lesser liberty can kings afford
Than harmless silence? Then afford it me.
Sufficeth, I may not, nor I will not tell thee.
KING: Fetch forth the tortures.
Traitor as thou art, I'll make thee tell.
HIER.:
Indeed,
Thou may'st torment me, as his wretched son
Hath done in murdering my Horatio,
But never shalt thou force me to reveal
The thing which I have vowed inviolate;
And therefore, in despite of all thy threats,
Pleased with their deaths, and eased with their revenge,
First take my tongue, and afterwards my heart. ${ }^{39}$

The fact that he silences himself after and not before he has given everything away is one side of the problem, the fact that the King does not seem to understand him, another. Usually this problematic passage is explained in terms of a

38 Griffin, Specter of Spain, p. 80, italics in the original.

39 Kyd, The Spanish Tragedy, 4.4.179-191. 
textual corruption that occurred between the lost edition of Jeffes and White's edition. But one may come to an altogether different conclusion: it could also refer to the fact that Hieronimo, as a representative of an overcome feudal and Catholic society, a society that is gone in England but still hovers in the air like a ghost, that this Hieronimo cannot talk to and be understood by the other characters who have come to represent the new episteme. The King simply cannot comprehend the words and deeds of somebody who represents a sign system which still belongs to the medieval aristocratic order of things. The King and especially the Machiavellian villain Lorenzo, on the other hand, stand for the modern episteme based on a conventional relationship between signifier, signified, and referent. As a result of this conflict, the representatives of both epistemes die on stage, and Spain is left without an heir and thus without a clear future direction. Only anxiety remains. The social, cultural, religious, and political crisis represented in Thomas Kyd's The Spanish Tragedy turns out to be an epistemic and an epistemological crisis. At the end of the play, everybody is left speechless. Or in Hamlet's words: "The rest is silence." 40

40 William Shakespeare, Hamlet, edd. Ann Thompson and Neil Taylor, The Arden Shakespeare, 3rd Series (London: Thomson Learning, 2006), 5.2.342. 